\title{
The Distinctness Condition in SLI: More on the Specific Externalization Impairment
}

\author{
GUILLERMO LORENZO \\ Universidad de Oviedo \\ glorenzo@uniovi.es \\ ORCID iD: 0000-0003-082I-28IX
}

\author{
Elena Vares \\ E. U. Gimbernat-Cantabria \\ elena.vares@eug.es \\ ORCID iD: 0000-0002-3193-9657
}

Recibíu / Received: I9-VII-20I8

Aceptáu / Accepted: I2-XII-20I8

ABSTRACT. This paper elaborates the idea that the externalization component of language is a particularly sensitive area of affectation of Specific Language Impairment. Based on data that relate to simple transitive constructions and interrogative and relative elaborations thereof, the thesis is explored that all the cases under scrutiny may receive a common explanation based on one prominent principle of the linearization procedure of externalization: namely, Distinctness. We conclude that children with Specific Language Impairment are not freed from this principle, but that they fulfill it by means of idiosyncratic strategies, relatively to the ones put forward by unimpaired speakers.

Keywords: SLI, Externalization, Linearization, Distinctness.

RESUMEN. Este trabajo desarrolla la idea de que el módulo de externalización lingüística es un punto de afectación particularmente sensible en casos de Trastorno Específico del Lenguaje. A partir de una muestra de construcciones transitivas, así como de elaboraciones interrogativas y relativas de este mismo tipo, se explora la hipótesis de que los casos considerados pueden recibir una explicación común basada en un principio especialmente prominente del procedimiento de alineación del mencionado módulo: en concreto, el principio de Distintividad. Se concluye que los niños con Trastorno Específico del Lenguaje no son ajenos a este principio, aunque lo satisfacen mediante estrategias idiosincráticas, en comparación con las empleadas por los hablantes sin afectación.

Palabras clave: TEL, Externalización, Alineación, Distintividad.

CÓMO CITAR / Form OF CiTATION: Lorenzo, Guillermo and Elena Vares (2019): "The Distinctness Condition in SLI. More on the Specific Externalization Impairment”, Glosema, I, pp. I I7-I 37. https://doi.org/I0.178 I I/glosema. I.20I9.I I 7-I37.

\footnotetext{
* This paper has benefited from a grant of the Spanish Government (DALiV: Development, acquisition and mechanisms of linguistic variation; FFI2017-87699-P). We want to express our gratitude to the following family associations for helping us in the experimental sessions with participants with SLI: ATELMA (Madrid), AFATEL (Extremadura), ATEL-CLM (Castilla-La Mancha) and TEL-Euskadi.
} 


\section{INTRODUCTION}

The syntax-phonology interface has been recently pinpointed as the main locus of affectation of Specific Language Impairment (henceforth, SLI) (Corver et al. 20I2). According to this view, "the language problem of children with SLI appears to lie $[\ldots]$ in the mapping of an adult-like syntactic representation onto a proper sound representation" (Corver et al. 20I2: 7I). Within this general background, it is reasonable to contend that problems of children with SLI are mostly to be found in the systems for sound production/discrimination (Phonology) and wording (Morphology), but that problems start at the linearization algorithm in charge of transforming a hierarchically structured syntactic representation onto a linearly organized sequence apt to be externalized (Linearization) (Tesnière 1959, Kayne I994, Chomsky 1995). This hypothesis has actually been advanced and experimentally tested before, with results suggestive that the idea is on track (Lorenzo \& Vares 2017).

In Lorenzo \& Vares 20I7, the general statement is made that the difficulties of children with SLI increase as a function of the number of candidate constituents to be linearized at a single phase ${ }^{1}$, an observation that they attest both in production and in comprehension tasks. For example, they find that interrogatives with an object WhP, wherein the object WhP and the subject DP end up at the same (upper) phase-as in (Ia), are more difficult to understand by children with SLI than interrogatives with a subject WhP, in which (reasonably) the subject WhP ends up at the upper phase and the object DP remains at the lower one, as in (Ib) ${ }^{2}$ :

(I) a. ¿A quién empuja la chica?

to who pushes the girl

'Who does the girl push?'

[CP=Ph2 a quién empuja la chica empuja [ ${ }^{\mathrm{P} P=\mathrm{Ph}}$ ta chica empuja quién

b. ¿Quién empuja a la chica?

who pushes to the girl

'Who pushes the girl?'

[CP=Ph2 quién empuja empuja $\left[{ }_{\nu \mathrm{P}} \mathrm{Ph}\right.$ I quién empuja a la chica

\footnotetext{
${ }^{1}$ In this paper, we follow a standard view on phases (with some qualifications to be explained), according to which two main domains count as phases at the sentence level: the full transitive projection $v \mathrm{P}$ (which contains an inner VP), and the full proposition plus force CP (which selects a TP); neither the VP or the TP are phases. So the following pattern obtains: $\left[\mathrm{CP}=\right.$ phase $\ldots \mathrm{C}\left[\mathrm{TP} \ldots \mathrm{T}\left[{ }_{\nu \mathrm{P}=\text { phase }} \ldots v[\mathrm{vP} \mathrm{V} \ldots\right.\right.$ The system sends the corresponding material to Externalization each time that it attains a phase level, with the putative exclusion of the head and edge of the corresponding category, which remains available for further operations. Cf. Chomsky 200I, 2008; for a general introduction to Phase Theory, cf. Citko 2014 .

${ }^{2}$ In these and all following examples, we use the copy theory of movement (Chomsky 1995), according to which repetitions of a single unit may be inserted at different locations and then deleted, except one (usually, the highest one). Deleted copies are represented by crossing them out.
} 
In the production side, among other effects, they observe that children with SLI tend to avoid regular movement (I-merging) operations, as a way of alleviating the linearization tasks at a single phase. (2), for example, illustrates a trend within Spanish speaking children with SLI, who usually opt for an atypical subject initial interrogative construction. Very likely, what happens in these cases is that children shortmove the Wh-word to a position within the lower phase, thus avoiding the need of linearizing it relatively to the subject at the upper phase:

(2) a. ¿el chico qué tiene?

the boy what has

'What does the boy have?'

[CP=Ph2 el chico [ ${ }_{\nu \mathrm{P} P \mathrm{Ph}}$ qué elehice tiene qué

b. ¿la niña cómo salta?

the girl how jumps

'How does the girl jump?'

[CP=Ph2 la niña $[\nu \mathrm{P}=\mathrm{Ph}$ ta niña cómo salta

Some of Lorenzo and Vares' observations, namely those relating to subject/object asymmetries, have been previously made regarding populations of children with SLI in different language communities (cf., among others, Lely \& Battell 2003), but their approach appears to offer a more principled explanation, since it relates these cases to other phenomena (e.g. who/which asymmetries in question formation, word order anomalies, anti pied-piping effects, etc.), which up to now have received unrelated, less congruous interpretations (Friedmann \& Novogrodsky 20 I I, Lely \& Battell 2003). However, there are aspects of Lorenzo and Vares' explanation that ask for a more fine-grained degree of theoretical definition. For example, they generically refer the problem of children with SLI to the Linearization procedure, arguing that limitations in the capacity for retaining items in working memory at each phase might be the ultimate mechanistic cause of these children's difficulties. This notwithstanding, an explanation might also be available capable of relating these children's problems with more specific conditions on Linearization.

The aim of this paper is precisely to argue in favor of that suggestion. With this aim in mind, we document different aspects of the linguistic performance of Spanish speaking children with SLI that might receive a more unitary and in-depth explanatory account if thought to reflect difficulties with Distinctness, a well-known condition on the Linearization procedure (Richards 20I0). The paper is organized as follows. In Section 2, children's difficulties in producing simple transitive constructions are illustrated and examined. This brief study is offered as a preliminary source of evidence suggestive of the idea that Distinctness putatively displays a somehow aberrant behavior in the case of children with SLI. Based on this preliminary clue, 
Section 3 introduces a heterogeneous family of phenomena, also taken from productions of Spanish speaking children with SLI, which appear to be also susceptible of being explained as showing different kinds of Distinctness-related misconducts. A general discussion (Section 4) closes this paper on the relevance of the cases under consideration for the syntax-phonology interface centered explanation of SLI.

2. Transitivity AVOIDANCE:

A SLI-TYPICAL REPAIR STRATEGY FOR DisTinCTNESS CONFLICTS

Once concluded that children with SLI have difficulties with the accumulation of to-be-linearized constituents within a single phase, it becomes inescapable trying to relate such a finding with recent advances in the understanding of the general dynamics of Linearization, like the ban on the linearization of items that the system perceives as identical. This particular condition, due to Richards (2010: 5), is speltout in (3):

(3) Distinctness

If a linearization statement $\langle\alpha, \alpha>$ is generated, the derivation crashes.

(3) entails that if a phase boundary ( $\nu \mathrm{P}$ or $\mathrm{CP})$ is attained and the corresponding material (i.e. the $v$ 's or C's complement) subserved to the phonological interface for externalization, the operation will crash unless the system perceives as sufficiently distinct the constituents that it must operate on. Just to refer a well-known example, drawing from Torrego (1998), Richards (2010: 28-29) argues that two specific animate DPs, one in the subject position and the other in the object position, end up at the same (upper) phase in Spanish. However, not being sufficiently distinct to the system, they cannot be linearized relatively to each other, as shown in (4a). Such a circumstance forces the object DP to show up as a KP (Kase Phrase), headed by the preposition $a$ 'to'. Such a repairing strategy is illustrated in (4b). Note that according to Richards' analysis, animate objects are located in the Spec of a C-like projection associated to the transitive $v \mathrm{P}$ system, responsible of the introduction of a phase partition:

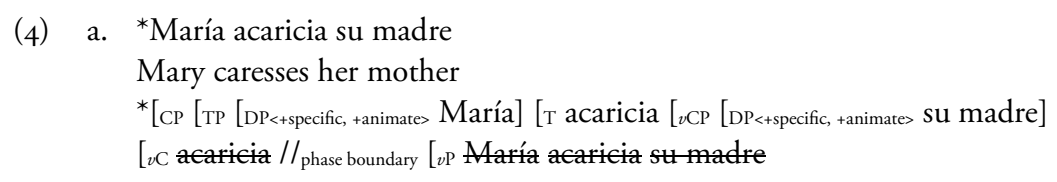

b. María acaricia a su madre

Mary caresses to her mother

'Mary caresses her mother'

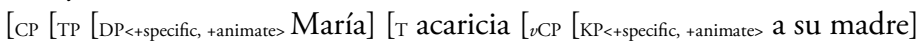

[ıc acaricia $/ /$ phase boundary $[\imath \mathrm{P}$ María acarieia a su madre 
Taking Richard's observation into consideration, we decided to explore how children with SLI behave regarding this particular Distinctness constraint, which affects a component of the linguistic system (Linearization) that we have independent reasons to believe to be selectively impaired in this pathological condition.

\section{I. Participants, materials, and results}

In order to verify this, we inspected the productions of 16 Spanish speaking children with SLI (age: 5; I to I 5;00; average: 8,9 ) in a previously carried out test aimed as an informal survey regarding these children's general ability to construct simple declarative sentences with different types of verbs. All children had an official SLI diagnosis, and they had passed tests that confirmed that they did not have other associated syndromes, like ASD (ADI-R and ADOS-G) or dyslexia (test on motor and cognitive development in relation to age), and that they ranked within normal levels of non-verbal intelligence (Leiter, TONI, non-verbal WISC). They attended standard schools and received special support there or in other institutions. Controls were selected that matched the children with SLI in age and had a similar socioeconomic and educational background.

The task that they were asked to fulfill consisted in describing, in as much detail as possible, a picture like the one in Figure I. Sometimes we needed to provide the verb for them, for otherwise they remained silent.

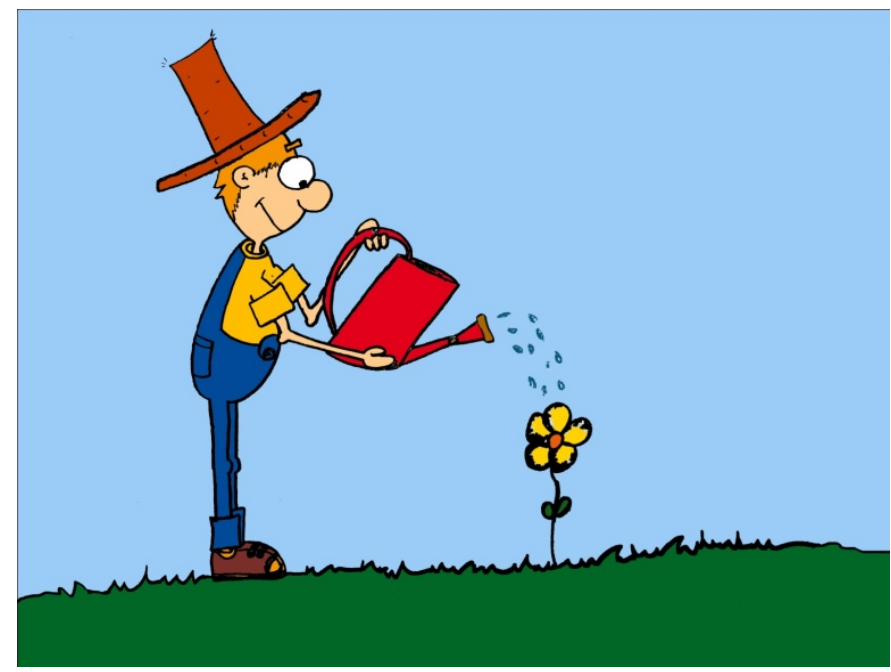

FIGURE I. Target sentence: El hombre riega la flor (lit. The man waters the flower) 
From all the collected data, only image/sentence pairings corresponding to transitive actions (like Figure I) were of interest for the current discussion, so we discarded all types of intransitive actions from the original sample. The trend then emerged that images corresponding to transitive actions were very commonly matched with constructions with a single argument, as examples like the ones in (5) to (9) show:

(5) $\mathrm{C}(5 ; \mathrm{I})$
a. El hombre riega
the man waters
Target A (El hombre riega la flor 'The man waters the flower')

b. El niño construye

the boy builds

Target B (El niño construye la casa 'The man builds the house')

(6) $\mathrm{V}(5 ; 7)$
a. regar la flor to water the flower
Target A
b. construye una casa
builds a house
Target B

(7) $\mathrm{A}(6 ; 9)$

está regando la flor is watering the flower

Target A

(8) $\mathrm{D}(7 ; 4)$

construir una casa

to build a house

Target B

(9) $\mathrm{CA}($ ( о ;2)
a. El chico está regar the boy is to water Target $\mathrm{A}$
b. El niño está construyendo the boy is building Target B


It became also apparent that two different strategies appear to be at work in these examples: Either the subject or the object is dropped out. Curiously, each particular child appeared to systematically use one or the other strategy, rather than alternating them. In other words, children appeared to more or less systematically behave either as subject-droppers or as object-droppers. Table I shows the particular percentage for each kind of production (complete, subject-drop, object-drop, and others) when used for matching transitive actions. The table basically reveals that droppings approximate complete productions, which means that they correspond to a bona fide trend in cases of SLI.

\begin{tabular}{|c|c|c|c|c|c|}
\hline & Complete & $\begin{array}{c}\text { Subject } \\
\text { drop }\end{array}$ & Object drop & Bare verb & No answer \\
\hline SLI group & $\begin{array}{c}85 / 160 \\
(53.1 \%)\end{array}$ & $\begin{array}{c}37 / 160 \\
(23.1 \%)\end{array}$ & $\begin{array}{c}33 / 160 \\
(20.6 \%)\end{array}$ & $\begin{array}{c}3 / 160 \\
(1.9 \%)\end{array}$ & $\begin{array}{c}2 / 160 \\
(1.3 \%)\end{array}$ \\
\hline C group & $\begin{array}{l}150 / 160 \\
(93.7 \%)\end{array}$ & $\begin{array}{c}3 / 160 \\
(1.9 \%)\end{array}$ & $\begin{array}{c}7 / 160 \\
(4.4 \%)\end{array}$ & $0 / 160$ & $0 / 160$ \\
\hline
\end{tabular}

TABLE I. Distribution of transitive action/sentence type pairings

\subsection{Analysis and discussion}

Examples (5) to (9) above lead us to conclude that the productions of children with SLI obey to a pattern that we shall refer to as "transitivity avoidance". It may be descriptively stated as in (Io):

(Io) Transitivity Avoidance (TA)

If a linearization statement $\langle\alpha, \alpha\rangle$ is generated at the $v \mathrm{P}$ level, drop out one $\alpha$.

Theoretically speaking, the identification of TA as a repairing strategy in the context of the Distinctness condition is relevant for two different reasons. On the one hand, TA is not, for rather obvious reasons, a repairing strategy that speakers without SLI can resort to. In their case, the systems of thought surely impose a pressure that in the case of children with SLI is not as restraining. In any event, TA is a strategy that populations of speakers with SLI resort to, so it must be added to the different kinds of strategies cross-linguistically attested as aimed at repairing Distinctness conflicts (e.g. adding or removing structure, blocking or forcing movement operations, etc.; Richards 2010). On the other hand, examples like the ones listed in (5) to (9) may be offered in support of a particularly intriguing aspect of Richards' theory, namely what he refers to as Derivational Distinctness (Richards 2010: I4): 


\section{(I I) Derivational Distinctness (DD)}

Given the choice between operations, prefer the operation (if any) that causes a Distinctness violation to appear as briefly as possible in the derivation.

This is an important point regarding our analysis, for the following reason. In the case of Spanish speakers without SLI, transitive versions of (5)-(9) above do not create Distinctness conflicts whatsoever. The putative objects of such versions are inanimate, which, according to Richards/Torrego's interpretation, remain $v \mathrm{P}$ internal and, thus, within the lower phase, as in (I 2). Correspondingly, no linearization problem arises, for the subject will end up at the upper phase (Spec, TP):

(I 2) $\left[\mathrm{CP}\left[\mathrm{TP}\left[\mathrm{DP}<+\right.\right.\right.$ specific, +animate $\mathrm{el}$ hombre] $\left[\mathrm{T}\right.$ riega $\left[{ }_{\nu \mathrm{CP}}\left[{ }_{\nu \mathrm{C}}\right.\right.$ riega $/ /{ }_{\text {phase boundary }}\left[{ }_{\nu \mathrm{P}}\right.$ el hombre riega $[\mathrm{DP}<+$ specific, -animate> la flor]

What (5) to (9) thus show is that, in the specific case of the SLI grammars, children sometimes apply DD in a "radical" way: As soon as a potential Distinctness conflict shows up, children react in the most radically possible way (e.g. dropping out a conflicting constituent, and detransitivizing the structure as a consequence). In (5) to (9) above, they appear to be doing exactly this—see ( 13 ), despite the fact that for speakers with unaffected grammars it is easy to repair the conflict by merely raising the subject by means of a routine instance of A-movement to Spec, TP.

(I3) [СР [TP [

\section{More SLI-typical Repair strategies: Subject avoidance}

Within the background of the previous section, we believe that an analysis of phenomena like (I) and (2) in Section I based on Distinctness conflicts becomes strongly motivated. Let's now concentrate on (2) and then introduce some related cases that in our opinion are apt to receive a common, principled explanation. As for (2), repeated below as ( 14 ), we interpret that the need of composing an interrogative expression is more pressing for the completion of an argument structure than in the case of simple declaratives. In any event, for children with SLI, the accumulation of constituents within a single phase continues to be particularly challenging. In these cases, they frequently resort to another strategy: Namely, the one of associating to $v$ the EPP feature that is routinely attached to $\mathrm{C}<+$ wh $>$ and instigates overt movement of the WhP to Spec, CP. Such an alternative strategy allows the WhP landing up in Spec, $v \mathrm{P}$, so within the lower phase, freeing children from the need of linearizing it relatively to the subject in the upper Spec, TP position. The suggested strategy therefore entails an idiosyncratic dissociation of the feature that specifies the interrogative force of the sentence (+wh) — in C, and the feature that instigates Wh movement (EPP)—in $v$ : 
(I4) a. ¿el chico qué tiene?

the boy what has

'What does the boy have?'

[ср $\mathrm{C}_{<+ \text {wh }>}$ [TP el chico $/ /$ phase boundary $\left[v \mathrm{p}\right.$ qué tiene $v_{<\mathrm{EPP}>} \ldots$

b. ¿la niña cómo salta?

the girl how jumps

'How does the girl jump?'

[СР $\mathrm{C}_{<+ \text {wh> }}$ [TP la niña $/ /$ phase boundary $\left[{ }_{\nu \mathrm{P}}\right.$ cómo salta $v_{<\mathrm{EPP}>} \ldots$

Obviously enough, this analysis also entails that, for children with SLI, DP and WhP are not sufficiently distinct categories, since, in the opposite case, they would not need to split them into two different phases. We believe that there exists independent motivation for granting that the idea is on track.

According to current theory, phrasal categories do not have a category of their own; they are rather labelled by features selected from the head's internal feature composition (Chomsky 2013). So in the case at hand, DP and WhP do not name but a certain asymmetry of the $\mathrm{D}$ feature and the Wh feature within the feature composition of their respective original holders. It is a well-established fact that children with SLI are, so to speak, "poor feature readers," a condition classically known as 'feature blindness' (Gopnik I990). So, leaving aside the ultimate nature of such a condition (cf. Vares 20 I7: I48-I 55; cf. also Grillo 2009, for a similar phenomenon in the case of aphasic agrammatism), what we simply suggest here is that at the level at which Linearization takes places (prior to word insertion, which is potentially capable of enriching the output in terms of feature content), children with SLI are not able to discern what the exact label of a given constituent is at the phrasal level (e.g. whether it is a $\mathrm{D}$ or a $\mathrm{Wh}$, two certainly related functional values). In other words, the corresponding constituents are not, contrarily to what happens to unaffected populations, sufficiently distinct in order to satisfactorily guide the fulfillment of Distinctness. For the sake of clarity, let's suppose that DPs and WhPs are in these cases confounded under the overarching category QP, in the sense that the systems of though, which appear to be spared in the case of these children, takes them to generically be scope-taking phrases within generalized quantifying structures (Gutiérrez-Rexach I 997). From now on, we shall label the corresponding phrases as QP, capturing this underlying identity, and differentiating them with subscripts expressing the kinds of features that we believe to be poorly read by children with SLI (like D, or Wh).

We would like to connect now examples like the ones in (I4) with another pattern that emerged from a close inspection of the results of tests focused on the production of interrogative sentences by children with SLI. 


\section{I. Participants, materials, and results}

Tests consisted of an elicitation task, wherein children were asked to construct questions (e.g. ¿Dónde encontró el niño el coche?; lit. where found the boy the car, 'Where did the boy find the car?'), based on the presentation of a picture and two extra clues: The expected answer to the question provided by a girl (e.g. debajo de la cama; lit. under of the bed, 'under the bed'), and a verb provided by her mother, which children were asked to use in their own productions (e.g. encontrar; 'to find'). Figure 2 shows this particular instance of the experiment. Children were trained in the task prior to the real test. Tests were conducted with I 2 children with SLI (age: I $0 ; 3$ to I $5 ; 0$, average: I $2 ; 7$ ) and I 2 unimpaired children (matched for age). Children under that age range did not understand the task and were consequently excluded. Children of the SLI and the Control group had profiles similar to those of the previous section.
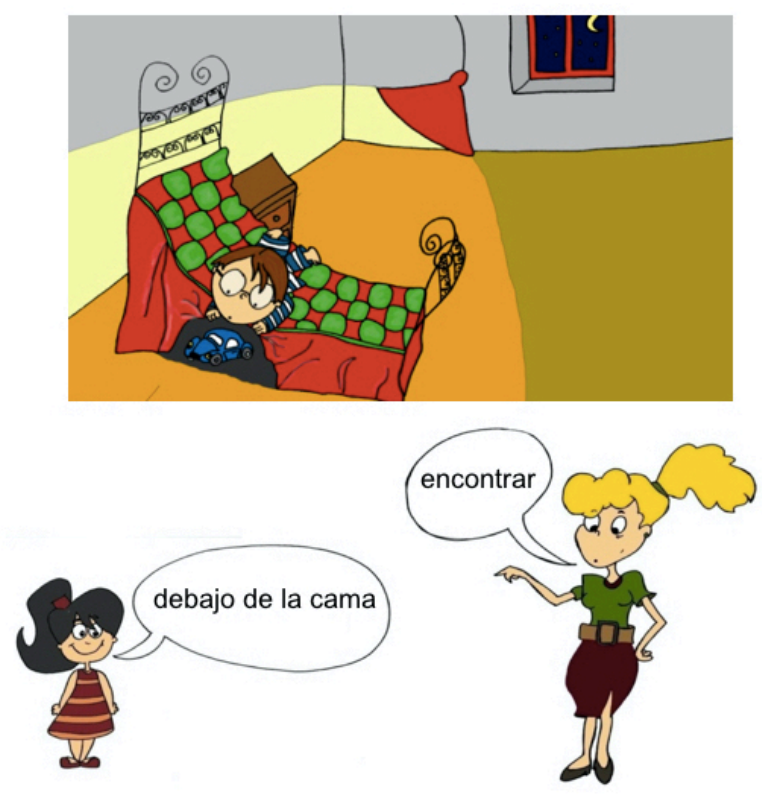

Figure 2. Target sentence: ¿Dónde encontró el niño el coche?

(lit. where found the boy the car; 'Where did the boy find the car?')

One of the patterns that emerged from the results was that the SLI group was more prone to drop out a constituent, normally the subject, than the control group. Besides, dropping the subject was more commonly associated to an adjunct WhP than to an argument WhP, which makes the case reminiscent of topic-drop phenomena in certain languages (Huang I984; cf. also Yang 2002, for related questions 
regarding unimpaired first language acquisition, and Vares 2016 , as regards acquisition in the context of SLI). ( 15 ) illustrates both types of examples with productions of the SLI group. Table 2 specifies their distribution in the SLI and in the Control group:

(is) a. Adjunct WhP + Subject drop

PB (I I ; )

¿Dónde ha encontrado el coche?

where has found the car

Target: 'Where did he find the car?'

b. Argument $\mathrm{WhP}+$ Subject drop

NG (Io;3)

¿A quién sirve?

to who serves

Target: 'Who is the waiter serving?'

\begin{tabular}{c|cccc} 
& $\begin{array}{c}\text { Correct produc- } \\
\text { tions }\end{array}$ & $\begin{array}{c}\text { Subject } \\
\text { drop }\end{array}$ & $\begin{array}{c}\text { Adjunct WhP }+ \\
\text { Subject drop }\end{array}$ & $\begin{array}{c}\text { Argument WhP } \\
\text { Subject drop }\end{array}$ \\
\hline SLI group & 142 & 43 & 30 & 13 \\
Cgroup & 240 & 11 & 10 & 1
\end{tabular}

TABLE 2. Distribution of interrogatives with subject omission ${ }^{3}$

\subsection{Analysis and discussion}

We suggest an interpretation of the examples in ( 15 ) along the following lines. Contrarily to what happens in examples like (I 4), children with SLI may choose the option of keeping the EPP feature associated as usual to $\mathrm{C}_{<+ \text {wh }}$, thus triggering runof-the-mill Wh movement to Spec, CP. When they do this, dropping the subject, which would otherwise occupy the Spec, TP position, is the most expedient way of avoiding a Distinctness conflict at the upper phase. We descriptively state the strategy in (I6):

(16) Subject Avoidance (SA)

If a linearization statement $<\mathrm{QP}_{<\mathrm{Wh}>}, \mathrm{QP}_{<\mathrm{D}>>}$ is generated at the $\mathrm{CP}$ level, drop out $\mathrm{QP}_{<\mathrm{D}>}$.

\footnotetext{
${ }^{3}$ Productions with subject drop were part of the correct productions. The third and fourth columns specify the kind of context wherein subject drop productions happened.
} 
However, (I6) does not readily explains the asymmetry reflected in Table 2: i.e. what makes children with SLI more prone to exercise (I6) when the WhPs are adjuncts than when they are arguments? The hypothesis that we suggest here takes advantage of Richards' (2010) proposal concerning the existence of a $v \mathrm{C}$ projection dominating the transitive $v \mathrm{P}$ structure. For concreteness, we suggest that adjuncts, not being properly part of the transitive component of the expression, are inserted (E-Merge) directly to $v \mathrm{C}$, and consequently are external to the phase boundary that this category introduces. This entails that a DP subject, in Spec, $v \mathrm{P}$, and an adjunct $\mathrm{WhP}$, in Spec, $v \mathrm{CP}$, are initially unrelated in terms of Linearization concerns, and thus they don't pose a problem to the system. However, when the DP moves to Spec, TP for licensing concerns, the resulting structure becomes more challenging to the system, for now both DP and $\mathrm{WhP}$ are within the same phase level, as in the intermediate derivational stage represented in ( $17 \mathrm{a}$ ). We claim that it is this circumstance that makes children recur to the strategy in (I6), avoiding the subject from the outset. Contrarily, when the $\mathrm{WhP}$ is an internal argument, moving the subject DP to Spec, TP serves to rescue an initially conflicting structure, as represented in ( 17 b) — conflicting configurations are stressed by an accompanying asterisk anteceding the relevant categories:

(I 7) a. $\left[{ }_{\mathrm{TP}} * \mathrm{QP}<\mathrm{D}>\left[{ }_{\mathrm{rcP}} * \mathrm{QP}_{<\mathrm{Wh}>} / /\right.\right.$ phase boundary $\left[{ }_{\nu \mathrm{P}} \mathrm{QP}_{<\mathrm{D}>\cdots} \ldots\right.$

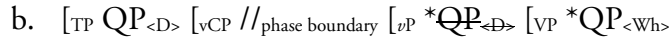

According to our interpretation of facts, it is this crucial derivational intermediate step that explains why avoiding the subject DP is a strategy particularly favored by children with SLI when the sentence also comprises an adjunct WhP. Whether the root $<{ }_{\mathrm{CP}} \mathrm{XP}\left[{ }_{\mathrm{C}} \mathrm{X}>\right.$ component of the (matrix) upper phase enter into linearization with the rest of the phase's material or it does independently, is a controversial issue (Salanova 2004). Note that, in the latter case, no further Distinctness conflict emerges in cases like ( $15 \mathrm{~b}$ ); but in the former, it does. In any event, within Richards' general DD framework, it makes sense to conclude that the contrast depicted in (I7) may be enough for children to favor (I 5a)-type subject dropping relatively to the ( 5 b)-type.

\section{More on Distinctness and SLI: Relative problems}

The ideas put forward in the previous sections raise certain predictions concerning other areas of grammaticality. We have seen that children with SLI appear to be eager to solve Distinctness problems, not differently from unimpaired children. In the case of simple transitives, they readily recur to the strategy of detransitivizing 
expressions by avoiding the externalization of either the internal or the external argument, as illustrated in examples (5) to (9) above. However, when they are more pressed to complete the argument structure of an expression, as when they are asked to construct a logical form with interrogative force, then they appear to make the effort to hold in working memory two conflicting constituents, with (so to speak) an eye put in the putatively alleviating effect of the next step required to the completion of the target logical form. This is captured in the abstract contrast depicted in (I7) above. This contrast entails that children with SLI are more permissive with Distinctness when the derivation proceeds from a more to a less conflicting structure, as in ( $17 \mathrm{~b}$ ) relatively to ( $17 \mathrm{a})$ - hence, the higher number of explicit subjects in the context of an argument operator than in the context of a non-argument operator. This case invites to formulate certain predictions regarding other expressions like relative sentences, in which basic argument constituents also merge with the expectancy that, later on, they may be logically manipulated.

\section{I. Participants, materials, and results}

A first prediction as regards relative clauses relates with the fact that in Spanish, as previously commented-see examples in (4), specific animate objects are prepositional (according to the previous comment, KPs), while garden variety objects are not (they are DPs). As also commented on, according to Richards' (2010: 28-29) interpretation, this is a Distinctness induced effect: Namely, a KP layer is added to the standard DP structure of the object, so the conflict is solved. Let's concentrate now in how children with SLI compound a subject relative in cases in which the subject and the object of the relative clause are both specific and animate. Considering the results of the previous subsection, our prediction is that the expectancy of I-Merging the subject to a position within an upper phase will act as a relieving factor of the need of fulfilling (Derivational) Distinctness at the lower phase (e.g. by deleting one or the other argument).

In order to verify this prediction, we conducted a test aimed at eliciting the production of subject relatives. The test comprised Io items, in which both the subject and the object made specific reference to persons. Children were given two images ( $\mathrm{A}$ and $\mathrm{B}$ ), and the examiner first described image $\mathrm{A}$ and then asked the children to compose a similar sentence to describe image B. Images were always very similar, except that males and females systematically exchanged their roles in the event from one image to the other. In order to avoid interferences, agents were always located at the left and patients at the right side of the image. The test started only after a series of trials made clear that children understood the task. Figure 3 offers an illustration. The test was carried out by I4 children with SLI (age: 6;8-I 5;0; average: 
I I;9), as well as I 4 unimpaired children (matched for age), with profiles similar to the ones of the previous sections.

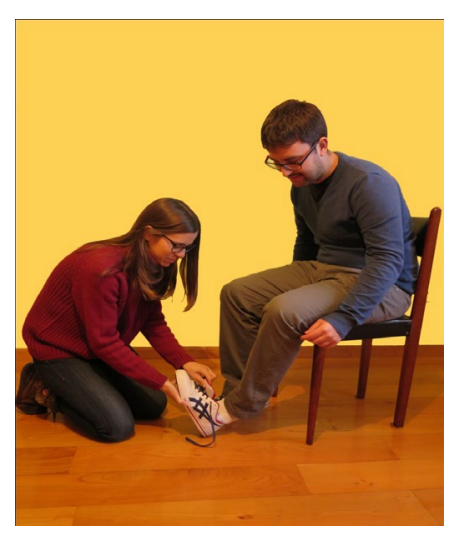

A

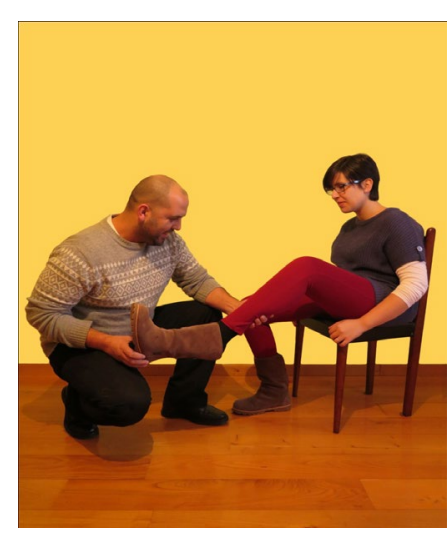

B

FIgURE 3. Experimenter's production: A. Es la chica la que calza al chico ('It is the girl who shoes the boy'); target: B. Es el chico el que calza a la chica ('It is the boy who shoes the girl')

According to our data, the prediction above is partially borne out, inasmuch as a certain number of the productions of children with SLI contains specific animate regular DPs, instead of KPs. (I 8) to (20) offer some relevant examples:

(I8) $\operatorname{LX}(6 ; 8)$

Es la chica que peina [DP el chico]

is the girl rel combs the boy

Target: Es la chica la que peina [KP al chico]

'It is the girl who combs the boy'

(i9) $\mathrm{MC}($ Iо; го)

Es la chica la que masajea [DP el chico]

is the girl det rel massages the boy

Target: Es la chica la que masajea [KP al chico]

'It is the girl who massages the boy'

(20) $\mathrm{SN}(13 ; 7)$

Es el chico que seca [Dp la chica]

is the boy rel dries the girl

Target: Es el chico el que seca [KP a la chica]

'It is the boy who dries the girl' 
However, this is not the whole story. Our data also show that children with SLI are not unaware, according to our interpretation, that speakers generally mark the internal and external argument differentially in this kind of configuration. Accordingly, the use of the preposition (a) is not absent from most of their productions. In any event, when they use it, another significant pattern emerges, namely, that they also tend to introduce the relative clause prepositionally. (2 I) to (24) illustrate this trend:

(2I) $\operatorname{LX}(6 ; 8)$

Es el chico al que empuja a la chica

is the boy prep-det rel pushes prep the girl

Target: Es el chico el que empuja a la chica

'It is the boy who pushes the girl'

(22) LX (6;8)

Es el chico al que seca a la chica

is the boy prep-det rel dries prep the girl

Target: Es el chico el que seca a la chica

'It is the boy that dries the girl'

(23) MC (го; го)

Es la chica a la que hace cosquillas al chico

is the girl prep det rel makes tickles prep-the boy

Target: Es la chica la que hace cosquillas al chico

'It is the girl that tickles the boy'

(24) PB (I I;2)

Es la chica al que masajea al chico

is the girl prep-det rel massages prep-the boy

Target: Es la chica la que masajea al chico

'It is the girl who massages the boy'

Finally, another common pattern within our data, actually the most common one, is illustrated in (25) to (28), in which the preposition (a) antecedes the relative, but is absent from the object:

(25) MC (I0;10)

Es el chico a la que seca la chica is the boy prep det rel dries the girl

Target: Es el chico el que sea a la chica

'It is the boy who dries the girl' 
(26) PB (I I;2)

Es el chico al que calza la chica is the boy prep-det rel shoes the girl

Target: Es el chico el que calza a la chica

'It is the boy who shoes the girl'

(27) NG (I 4; I I)

Es la chica al que pellizca el chico is the girl prep-det rel pinches the boy

Target: Es la chica la que pellizca al chico

'It is the girl who pinches the boy'

(28) $\operatorname{LB}(\mathrm{I} 5 ; \mathrm{O})$

Es la chica a la que peina el chico is the girl prep det rel combs the boy

Target: Es la chica la que peina al chico

'It is the girl who combs the boy'

Productions of type (I 8) to (28), correspond to $30 \%$ of total productions in our records of the SLI group. Let's collectively refer to them as the "mutant" (M) types, and discriminate between them as $\mathrm{MI}_{-}$( I 8) to (20), M2-(2 I) to (24), and $\mathrm{M}_{3}-$ $(25)$ to (28), respectively. Percentage of "wild" (W) type productions (i.e. subject non-prepositional relative + prepositional object) is $33 \%$. The remaining $37 \%$ corresponds to productions that approximate the "wild" type, yet containing different kinds of "errors", unrelated to the concerns of this paper. Within the M category, types rank as follows: $M_{I}=I_{9} \% ; M_{2}=3 \mathrm{I} \% ; M_{3}=50 \%$-see Table 3.

\begin{tabular}{|c|c|c|c|c|c|}
\hline \multirow[b]{3}{*}{ SLI group } & \multicolumn{2}{|l|}{$W$-type } & \multicolumn{2}{|l|}{ M-type } & Others \\
\hline & \multirow{3}{*}{$33 \%$} & \multicolumn{3}{|c|}{$\begin{array}{c}30 \% \text {, } \\
\text { of which }\end{array}$} & \multirow{3}{*}{$37 \%$} \\
\hline & & M1 & M2 & M3 & \\
\hline \multirow{4}{*}{ C group } & & $5.7 \%$ & $9.3 \%$ & $15 \%$ & \\
\hline & \multirow{3}{*}{$90 \%$} & \multicolumn{3}{|c|}{$\begin{array}{l}2.9 \% \\
\text { of which }\end{array}$} & \multirow{3}{*}{$7.1 \%$} \\
\hline & & M1 & M2 & M3 & \\
\hline & & $0.75 \%$ & $0.75 \%$ & $1.4 \%$ & \\
\hline
\end{tabular}


W: Non-prepositional subject relative + prepositional object.

M1: Non-prepositional subject relative + non-prepositional object

M2: Prepositional subject relative + prepositional object

M3: Prepositional subject relative + non-prepositional object

Others: Agreement errors, omissions, etc.

TABLE 3. Typology of productions for specific animate subject relatives + specific animate object

\subsection{Analysis and discussion}

We assume a Kayne (1994)-style analysis for relatives, according to which the relative clause is a CP, headed by the relative pronoun, that contains both the internal and the external arguments. This CP, in turn, is embedded within a DP. The N head of one or the other argument within the embedded CP moves and ends up at the $\mathrm{N}$ position of the higher DP level, roughly as in (29), which represents a subject relative when concurrent with a specific animate object:

(29) $\left[\mathrm{DP} \mathrm{D}\left[\mathrm{sN} N\left[\mathrm{CP}\right.\right.\right.$ rel //phase boundary $\ldots\left[{ }_{\nu \mathrm{P}}\left[\mathrm{DP} \mathrm{D}_{\varnothing}[\mathrm{SN} \mathrm{N}] \ldots[\mathrm{KP}[\mathrm{DP} \ldots\right.\right.$

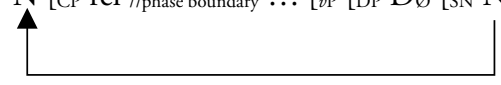

Some clarifications about (29) are in order. Firstly, we unproblematically interpret that the original structure of the external argument is a DP, the head of which is a null determiner $\left(\mathrm{D}_{\varnothing}\right)$. So putting some flesh on a skeleton like (29), something like (30) obtains:

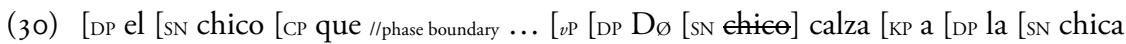
the boy who shoes to the girl

Secondly, it must be taken into account that, in our test, target relatives were systematically embedded within cleft constructions, a pattern that sometimes is respected in the productions of children-e.g. (I9), but sometimes is not-e.g. (I8). This causes the relative to be headed by an empty noun, which is unproblematically interpreted as identical to the one cleft, as represented in (3I) - not spelt out material has been omitted from the gloss:

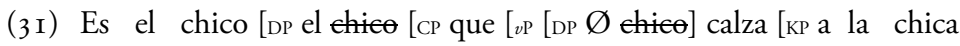
is the boy the who shoes to the girl

Turning now to our interpretation of (I8) to (20) above, the part of the external DP argument that is sent to externalization-i.e. $\mathrm{N}$ in (29), enters into Linearization at a phase different from the one of the internal argument. Nevertheless, in the case of speakers without SLI, Derivational Distinctness forces them to E-Merge an internal KP argument from the onset of the derivation. Contrarily, children with SLI appear to be confident of the repairing effect of I-Merging (part of) the external DP 
argument to a higher position, so they don't find problematic E-Merging the conflicting internal DP argument as such-(32), which we see as a particular instance of the pattern previously depicted in $(\mathrm{I} 7 \mathrm{~b})$ above:

(32) $\left[\mathrm{DP} \mathrm{D}\left[\mathrm{sN} N \mathrm{~N}\left[\mathrm{CP}\right.\right.\right.$ rel //phase boundary $\ldots\left[{ }_{\mathrm{vP}}\left[\mathrm{DP} * \mathrm{D}_{\varnothing}[\mathrm{sN} \mathrm{N}] \ldots{ }^{*}[\mathrm{DP} \ldots\right.\right.$

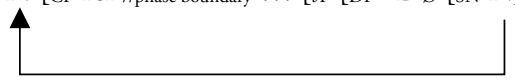

As for (2I) to (24), the preposition that antecedes the relative clause is in all cases superfluous. A reasonable way of making sense of its being there is that it functions as an agreement-like element, which signals the probe-goal relation with the preposition that introduces the specific animate object. We thus interpret that children do not use this latter preposition as a tool for solving a Distinctiveness conflict, but just for mimicking an idiomatic practice that makes them to introduce into the expression non-interpretable material, which they are also eager to get rid of by a 'bombing' probe-goal (P-G) strategy (Chomsky 200I). This is illustrated in (33):

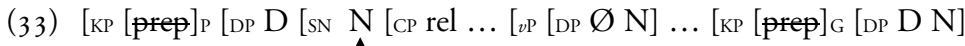

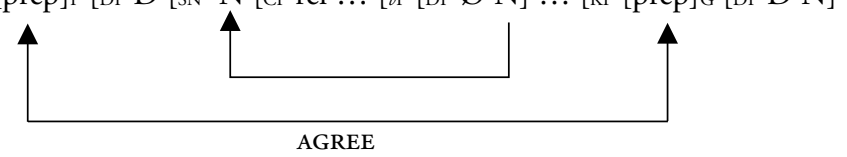

Let's elaborate a little bit on what we mean by saying that children bomb away these prepositions. As already noted, we believe that they are using them merely for mimicking a prominent and pervasive practice around. So our guess is that children resort to AGREE in these cases as a way of dealing with units that, not being interpretable, raise the expectation that something must be done with them. The something is not innocent here, since we actually mean some or another thing: The strategy they resort to is not necessarily the one illustrated in (33), but also the one instantiated in examples (25) to (28). In these latter cases, our interpretation is that children fulfill the compulsion to do something with the preposition resorting to MOVE, instead of AGREE, as represented in (34):

(34) $\left[\mathrm{KP}[\mathrm{prep}]_{\mathrm{P}}\left[\mathrm{DP} \mathrm{D}\left[\mathrm{sN} \mathrm{N}\left[\mathrm{CP} \operatorname{rel} \ldots\left[{ }_{\imath \mathrm{P}}[\mathrm{DP} \varnothing \mathrm{N}] \ldots\left[\mathrm{KP}[\mathrm{prep}]_{\mathrm{G}}[\mathrm{DP} \mathrm{D} \mathrm{N}]\right.\right.\right.\right.\right.\right.$

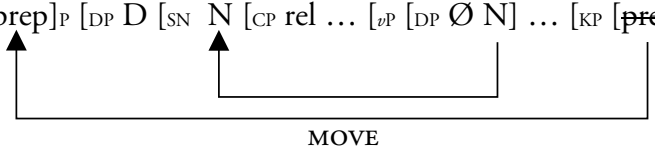

MOVE

Note that it is not difficult to assimilate (33) and (34), considering that MOVE, according to Chomsky's (1995) deconstruction, may be unproblematically conceptualized as an instance of AGREE, followed by DELETION of the lower copy.

Table 3 shows that children with SLI use prepositional objects (KP) in the configuration of concern at random, as reflected by the fact that productions with and 
without preposition are almost equally frequent. According to our interpretation, this may be due to their inability to consistently use the preposition as a strategy for solving Distinctness conflicts. For them, other strategies appear to be as satisfactory as the addition of the KP layer to the object DP, which means that they are not as strongly constrained by Derivational Distinctness as other speakers. They may choose to start the derivation with two DPs within the lower $v \mathrm{P}$, violating Derivational Distinctness, yet subsequently overcoming a general Distinctness failure thanks to the displacement of the external argument up to a higher phase.

The observation that MI-type productions are the less preferred ones may be due to the fact that it strongly departs from the convention of inserting prepositions in these kinds of sentences. Children are consequently more inclined to insert prepositions, which for them merely work as functional units that enable computational operations, yet without a clear designated mission. Torrego (1998) claims that the nature of $a$ in Spanish may differ from case to case, so in some cases it is a syntactic head $(\mathrm{K})$ that adds structure to the expression (KP; $\mathrm{K}$ and $\mathrm{KP}$ are taken from Richard's [20Io] elaboration of the idea), but in some other cases does not. One way of interpreting the case of Spanish speaking children with SLI is that, for them, $a$ does not project structure in general and that it merely acts as a functional element that instigates "dummy" computational activity.

Finally, our suggestion regarding the fact that $\mathrm{M}_{3}$-type productions, with deletion of the lower copy, outcompete M2-type productions, is that the former are more highly ranked than the latter from the point of view of Externalization economy, considering Chomsky's (2005: I3) thesis that deletion of lower copies is in general a clear reflex of the relative strength of economy (which privileges spelling out just one copy) over full interpretation (which would privilege spelling out as much material as possible), an optimization principle that children with SLI appear to unproblematically respect.

\section{Conclusions}

This paper provides evidence in support of the idea that problems of children with SLI accumulate on the Linearization procedure, at the onset of the Externalization component of language, along the lines previously advanced in Lorenzo and Vares 2017. Within this framework, we have interpreted some new data that putatively point to a more nuanced version of the idea, since the explanation relies on a particular aspect of the linearization dynamics, namely Richards' (20 I0) Distinctness condition. Our conclusion is not that children with SLI are unaware of this 
constraint, but that they deal with it idiosyncratically, in that their linguistic performance appears to obey to repairing strategies that depart from the ones of other speakers.

Specifically, we have identified and explained the following trends:

(I) Firstly, children with SLI are particularly prone to delete an argument in simple transitive constructions, which we interpret as a "radical" way of fulfilling Richards' (sub) principle of Derivational Distinctness. At first sight, this strategy appears to be extremely idiosyncratic of children with SLI, yet it might shed some light upon common deletion phenomena in speakers without the same condition.

(2) Secondly, the ordinary strategy for differentiating two DPs within the same phase by adding a prepositional layer (KP) to one of them is, at first glance, also used by children with SLI. However, a close inspection reveals that their performance is again idiosyncratic in this respect. On the one hand, the preposition is utterly absent in some cases, in which they rely on other strategies to fulfill Distinctness, like moving one of the concurring DPs out of the "overcrowded" phase. On the other hand, the preposition shows up in some other cases, but there exist signals that it is processed in an uncommon way, probably as an agreement marker (as when they use it twice), or as a lower copy (which they opt to delete). This second family of cases is also revealing of the fact that children with SLI are not as constrained to fulfill Derivational Distinctness as other speakers.

All the cases reviewed in this paper also reinforce the conclusion that SLI-associated grammars obey to the same design constraints as unaffected grammars. Children with SLI mostly manifest difficulties in dealing with the kinds of languagespecific material provided by UG (e.g. non-interpretable prepositions), but if one focuses on the background of third factor effects on which language design mostly depends on (Chomsky 2005), the conclusion is reached that the grammars that these children use are clearly continuous in relation to the grammars of non-affected children and adults.

\section{REFERENCES}

CHOMsky, Noam (I 995): The Minimalist Program, Cambridge (MA): The MIT Press.

CHOMSKY, Noam (2001): "Derivation by phase", in Michael Kenstowicz (ed.), Ken Hale: A Life in Language, Cambridge (MA): The MIT Press, pp. I-5 I.

CHOMsкy, Noam (2005): “Three factors in language design”, Linguistic Inquiry, 36(I), pp. I-22. https://doi.org/IO.I I62/0024389052993655. 
CHOMSKY, Noam (2008): "On phases", in Robert Freidin, Carlos P. Otero and María Luisa Zubizarreta (dirs.), Foundational Issues in Linguistic Theory: Essays in Honor of Jean-Roger Vergnaud, Cambridge (MA): The MIT Press, pp. 29I-32I.

https://dx.doi.org/I 0.755 I/mitpress/9780262062787.003.0007.

CHOMSKY, Noam (2013): "Problems of projection”, Lingua, I30, pp. 33-49. https://doi.org/ I o. I I I6/ j.lingua.201 2.12.003.

Ciтко, Barbara (2014): Phase Theory. An Introduction, Cambridge: Cambridge University Press. https://doi.org/Io. I o I7/CBO978 I I 39644037.

CORVER, Nobert, Frenette SOUTHWOOD and Roeland VAN HOUT (2012): "Specific Language Impairment as a syntax-phonology (PF) interface problem: Evidence from Afrikaans", Stellenbosch Papers in Linguistics, 4I, pp. 7 I-89. http://dx.doi.org/I0.5774/4I-O-I 34.

FriedmanN, Naama and Rama NOVOGRODSKY (201 I): "Which questions are most difficult to understand? The comprehension of Wh questions in three subtypes of SLI", Lingua, I 2 I (3), pp. $367-$ -382. https://doi.org/I0.1016/j.lingua.2010.10.004.

GopNIK, Myrna (1990): "Feature blindness: A case study", Language Acquisition, I(2), pp. I39-I64. https://doi.org/IO.I207/sI 53278 I 7 lao IO2_I.

GRILLO, Nino (2009): "Generalized Minimality: Feature impoverishment and comprehension deficits in agrammatism”, Lingua, I I9(Io), pp. I426-1443.

https://doi.org/I0.1016/j.lingua.2008.04.003.

GUTIÉRREZ-REXACH, Javier ( I997): "Questions and generalized quantifiers”, in Anna Szabolcsi (ed.), Ways of Scope Taking, Dordrecht: Kluwer, pp. 409-492.

HUANG, C.-T. James (1984): "On the distribution and reference of empty pronouns", Linguistic Inquiry, I $5(4)$, pp. 53 I-574.

KAYNE, Ricahrd (I994): The Antisymmetry of Syntax, Cambridge (MA): The MIT Press.

LELY, Heather K. van der and Jackie BATTELL (2003): "Wh-movement in children with grammatical SLI: A test for the RDDR hypothesis", Language, 79(I), pp. I 53 -I 8 I. https://doi.org/IO.1353/lan.2003.0089.

LORENZO, Guillermo and Elena VARES (2017): "The externalization component as the locus of specific impairments", Biolinguistics, I I, pp. I-I9.

RICHARDS, Norvin (2010): Uttering Trees, Cambridge (MA): The MIT Press. https://doi.org/I0.755I/mitpress/9780262013765.001.000I.

SALANOVA, Andrés (2004): "Inversion in Spanish interrogatives", unpublished manuscript, Massachusetts Institute of Technology.

TESNIÈRE, Lucien (1959): Éléments de syntaxe structurale, Paris: Klincksieck.

TORREgO, Esther (1998): The Dependencies of Objects, Cambridge (MA): The MIT Press.

VARES, Elena (2016): "Topic-drop residual en el Trastorno Específico del Lenguaje. Una interpretación desde la perspectiva del desarrollo", Revista Española de Lingüistica, 46(I), pp. I 59-I69.

VARES, Elena (20I7): Fenomenología lingüistica de los trastornos especificos del lenguaje [Ph Dissertation], Oviedo: Universidad de Oviedo.

YANG, Charles D. (2002): Knowledge and Learning in Natural Language, Oxford: Oxford University Press. 